\title{
Histopathology of Eosinophilic Esophagitis
}

\author{
Margaret H. Collins \\ Division of Pathology and Laboratory Medicine, Cincinnati Children's Hospital Medical Center, \\ University of Cincinnati, Cincinnati, Ohio, USA
}

\author{
Key Words \\ Eosinophilic esophagitis · Pathology · Differential diagnosis . \\ Gastroesophageal reflux disease · Proton pump \\ inhibitor-responsive esophageal eosinophilia
}

\begin{abstract}
Eosinophilic esophagitis (EoE), a chronic relapsing antigendriven disease, is associated with characteristic esophageal histopathology, including $\geq 15$ intraepithelial eosinophils in at least one high-power field (HPF), and alterations in the epithelium and subepithelial connective tissue. Currently, the pathologic changes in EoE are characteristic but not pathognomonic: the differential diagnosis includes gastroesophageal reflux disease, proton pump inhibitor-responsive esophageal eosinophilia, EoE with significant eosinophilic inflammation in other parts of the gastrointestinal tract (eosinophilic gastrointestinal disorder), etc. EoE biopsy pathology does not vary according to age, sex, or familial predisposition. Genetic analyses of EoE esophageal biopsies have identified a characteristic transcriptome that includes upregulation of several genes that relate to histopathology, such as periostin, thymic stromal lymphopoietin, and desmoglein. Diagnostic pitfalls include the patchy distribution of the characteristic EoE pathology; examining multiple biopsies increases the disease detection rate. The method used to quantitate eosinophils, including the size of the HPF,
\end{abstract}

influences the diagnostic yield, but excellent interobserver variability is achieved among pathologists who agree to a uniform methodology. Therapy for EoE includes diet-based approaches to eliminate offending antigens, topical steroid therapy, and novel biologic agents including monoclonal antibodies. Following appropriate therapy, biopsies may revert to normal histology, but signs and symptoms of esophageal dysfunction may persist. A potential explanation is that endoscopic biopsies obtain very small superficial fragments of tissue from an organ that has complex underlying neuromuscular components; unseen pathology in those loci may influence the clinical state of patients with normal epithelial biopsies.

c 2014 S. Karger AG, Basel

Eosinophilic esophagitis (EoE) is an inflammatory esophageal disease that has characteristic clinical findings indicating esophageal dysfunction and eosinophilpredominant inflammation in the esophageal epithelium [1]. A conceptual definition has emerged of EoE as a chronic disease resulting from immune/antigenic stimulation [2-5]. An exceedingly important component of the definition is that EoE is a clinicopathologic diagnosis - neither biopsies nor clinical findings can be used in isolation to diagnose the disease; both are required.

\section{KARGER}

E-Mail karger@karger.com

www.karger.com/ddi (c) 2014 S. Karger AG, Basel

0257-2753/14/0322-0068\$39.50/0
Prof. Margaret H. Collins, MD

Division of Pathology and Laboratory Medicine, ML 1035

Cincinnati Children's Hospital Medical Center

3333 Burnet Ave., Cincinnati, OH 45229 (USA)

E-Mail margaret.collins@cchmc.org 


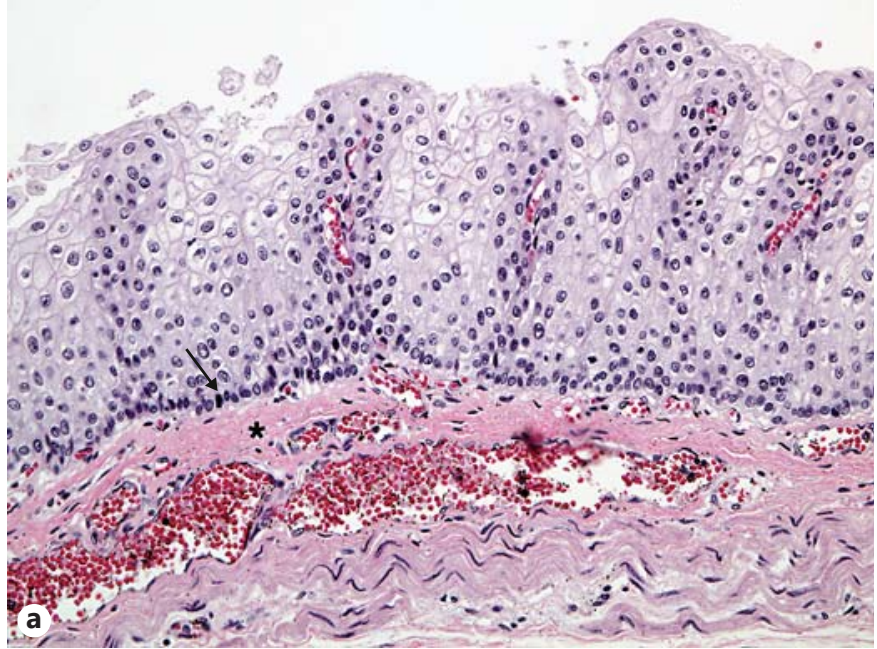

Fig. 1. a Normal esophageal squamous epithelium exhibits a basal layer that is not more than 3 cell layers thick or more than $15 \%$ of the total epithelial thickness (bar with arrow). Lamina propria is not thickened (asterisk). b Esophageal epithelium from a patient with EoE shows a markedly thickened basal layer (bar), numerous intraepithelial eosinophils (arrows), dilated intercellular spaces (white arrow), and thickened fibers in the lamina propria (asterisk). c In this EoE biopsy that is not well oriented, peripapillary basal layer hyperplasia is apparent (bar). Numerous intraepithelial eosinophils are seen including eosinophil abscesses at the surface (arrows). Dilated intercellular spaces are also seen (white arrow).

\section{Microscopic Pathologic Features}

\section{Inflammatory Cells}

The most characteristic microscopic pathologic feature of EoE is intraepithelial eosinophil inflammation (fig. 1). Eosinophils are normally found in the mucosa of the gastrointestinal tract, except for the esophagus [6]. Eosinophils are easily recognized in sections of tissue, fixed in formalin, that are stained with hematoxylin and eosin; special stains are not required. Frequently, esophageal biopsies at the time of EoE diagnosis demonstrate very large numbers of intraepithelial eosinophils that may form abscesses and align parallel to the luminal surface $[1,4,7]$. Methods of counting eosinophils vary and the
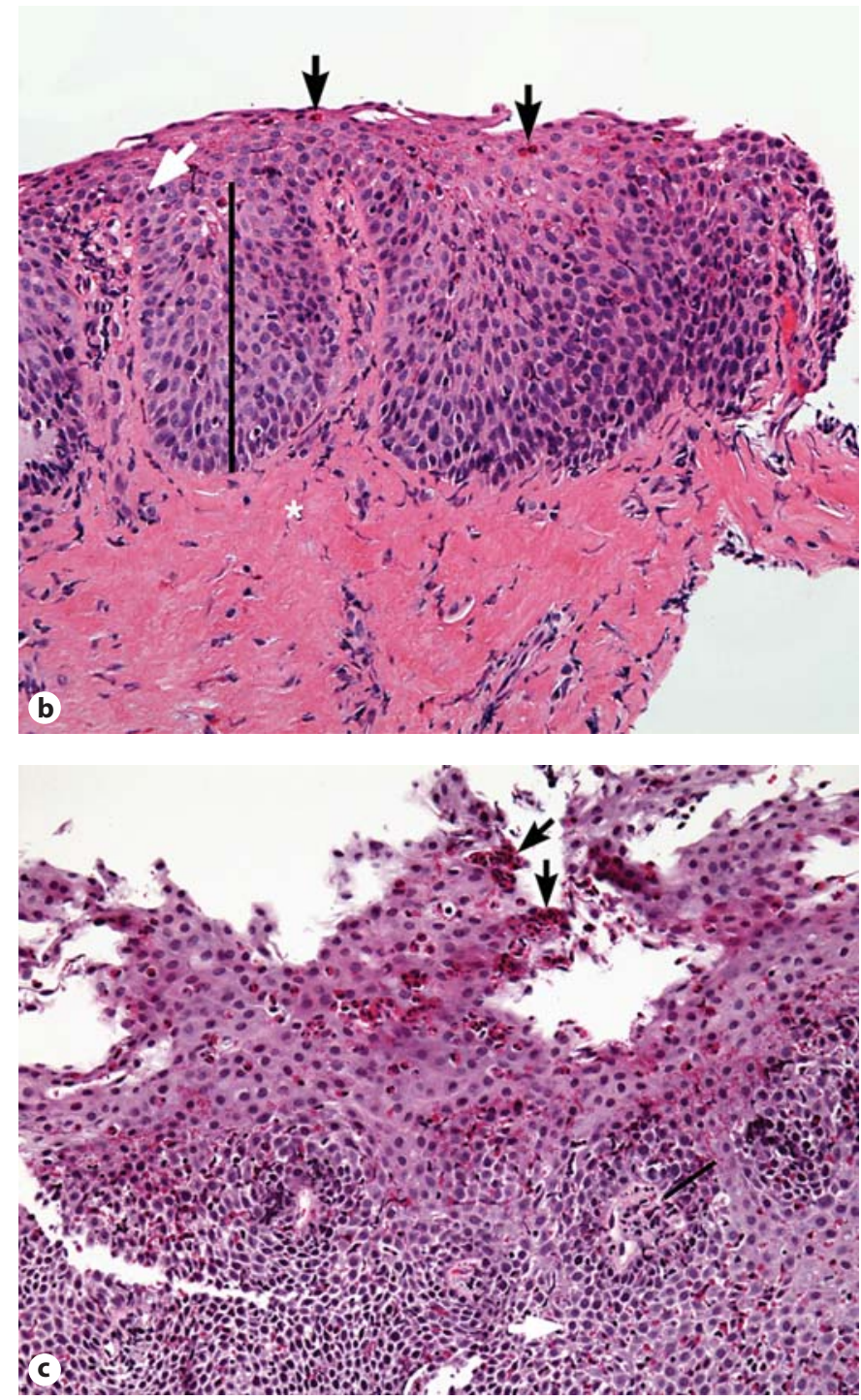

size of the microscopic field in which they are counted may vary significantly among microscopes, which complicates the ability to compare counts obtained from different pathologists and even counts obtained in the same pathology department over time. Expressing the eosinophil number per unit area would help to diminish variations, and in fact excellent interobserver agreement is achieved among pathologists who decide upon and routinely use selected methods of evaluating EoE biopsies [8]. Mean counts obtained from quantitating eosinophils in several or all highpower fields (HPF) in esophageal biopsies may be suitable for research purposes, but currently a carefully obtained peak count is sufficient to suggest that, in the proper clinical setting, a biopsy is consistent with EoE. 
EoE may be distributed in a patchy manner throughout the esophagus, impairing the ability to diagnose the disease. Increasing the number of biopsies submitted for histologic examination increases the diagnostic yield, and examining 5 biopsies increases the yield to $100 \%$ for a threshold peak count of $\geq 15$ eosinophils/HPF [9]. Patchy distribution of eosinophil infiltrates may result in biopsies showing eosinophil inflammation, but the peak eosinophil count is less than the recommended threshold value for diagnosis of 15/HPF; EoE is a clinicopathologic diagnosis and clinical judgment is required to determine if individuals whose biopsies do not display $\geq 15$ eosinophils/HPF have EoE [4]. Pathologists should obtain additional sections of such biopsies because deeper sections may yield higher counts. Eosinophil infiltrates having a peak count $\geq 15 / \mathrm{HPF}$ peak count may be found in proximal esophageal biopsies in patients who have gastroesophageal reflux disease (GERD) or proton pump inhibitor-responsive esophageal eosinophilia (PPI-REE) and therefore are not pathognomonic of EoE [10]. Abnormalities of the mucosa identified at endoscopy of EoE are characteristic [11], but the mucosa may appear normal in a significant number of patients [2], and normal gross mucosal appearances should not deter endoscopists from obtaining biopsies from patients with characteristic EoE clinical findings. Biopsies from the stomach and duodenum should also be obtained to identify eosinophil-related or other pathologies at those sites. As with esophageal biopsies, biopsies at those sites should be obtained even if the mucosa appears normal because, for example, children and adults who have eosinophil gastritis may have normal-appearing gastric mucosa at endoscopy [12].

Other inflammatory cells including lymphocytes and mast cells are increased in esophageal biopsies from patients who have EoE [13-16], and generally their increase parallels the increase in eosinophils.

\section{Additional Pathology}

The epithelial alterations most characteristic of EoE are basal layer hyperplasia and dilated intercellular spaces (fig. 1). Biopsy orientation may diminish the ability to evaluate hyperplasia, but significant hyperplasia can be appreciated even in tangentially oriented sections. Dilated intercellular spaces are often seen, with or without basal layer hyperplasia. The epithelial alterations tend to be most impressive in biopsies that contain large numbers of intraepithelial eosinophils [1], but some biopsies with apparently few eosinophils show marked hyperplasia and intercellular space dilation; these may be biopsies in which eosinophil concentrations are quite patchy. Lamina propria may show changes suggestive of fibrosis/remodeling [17-19], which may be reversible [20-22]. Many esophageal biopsies obtained endoscopically do not exhibit lamina propria.

\section{History and Significance of EoE Pathology}

Although allergic esophagitis is an apparently new disease, the histopathology of EoE is not new. Review of esophageal biopsy slides obtained from adults and children prior to the recognition of EoE as a disease entity has confirmed that esophageal biopsies contained numerous intraepithelial eosinophils and associated pathology, including eosinophil abscesses, basal layer hyperplasia, and lamina propria fibrosis [23-26]. The significance of intraepithelial eosinophils in esophageal biopsies is emphasized by the fact that patients who had intraepithelial eosinophils (as few as 5/HPF in esophageal biopsies and were not treated for EoE with antigen elimination, etc.) were significantly more likely to experience dysphagia and food impaction in subsequent years compared to patients whose biopsies contained less than 5 eosinophils/ HPF [27].

\section{Differential Diagnosis}

These esophageal epithelial pathologic features are not pathognomonic of allergic EoE. Esophageal epithelial biopsies obtained from patients who have systemic disorders such as hypereosinophilic syndrome may show these features, as well as patients who have significant eosinophil infiltrates in the mucosa of one or more other sites in the gastrointestinal tract (eosinophilic gastrointestinal disorder) or unrelated diseases such as celiac disease or idiopathic inflammatory bowel disease $[1,4,5]$. Predisposing conditions include a family history of EoE [28] and a connective tissue disorder characterized by hypermobility [29]. There are no features on hematoxylin and eosinstained slides that identify subjects with predisposing or associated conditions from those without such history.

More common causes of esophageal biopsies that show the features of allergic EoE are GERD [30, 31] and PPI-REE [10, 32-35]. PPI-REE is increasingly being recognized as a cause for clinical findings and biopsies that resemble EoE. There are no pathologic features that predict response to PPI [32-35]. The clinical and histologic responses may be transient [33], and close clinical followup is prudent. Whether PPI-REE represents an unusual phenotype of GERD or EoE is not yet known [36]. 
Distinguishing biopsies of EoE from GERD would be helpful clinically to reduce additional testing and accelerate the time to a proper diagnosis. In esophageal biopsies obtained from children, mast cell activation defined as IgE-positivity has been suggested to distinguish EoE from GERD [37]; however, the patient populations in the study were assigned diagnoses based on intraepithelial eosinophil counts, and additional crucial clinical information such as use of PPI or results of $\mathrm{pH}$ monitoring was not provided. In biopsies obtained from children and adults diagnosed with EoE or GERD according to consensus guidelines, mast cells were significantly increased in EoE biopsies compared to those from patients who had GERD, and the combination of peak eosinophil count plus the number of mast cells successfully distinguished the groups in a high proportion of cases [38]. However, the number of intraepithelial eosinophils in the GERD biopsies was significantly less than the number in EoE biopsies. In a study of esophageal biopsies from patients who had EoE (normal pH monitoring results) versus GERD (abnormal $\mathrm{pH}$ monitoring results) and increased intraepithelial eosinophil counts that did not differ between the groups, the median but not mean number of tryptase-positive mast cells was increased in EoE compared to GERD [39]. Some of these patients, however, may have had PPI-REE. More studies of mast cells in esophageal biopsies of patients with EoE and patients with GERD who have comparable amounts of eosinophilic inflammation are required to determine if mast cells can distinguish the diseases.

\section{Therapy}

Several prospective randomized placebo-controlled clinical trials of various therapies to treat EoE have been reported. Topical corticosteroid therapy, in the form of swallowed fluticasone in children [40] and adults [41] or oral budesonide in children [42], adolescents, and adults [43], reduced eosinophilic inflammation in esophageal epithelium consistently. Monoclonal antibodies to IL-5 also significantly reduced intraepithelial eosinophilic inflammation in esophageal biopsies from children enrolled in trials that tested the efficacy of high doses versus low doses of antibody [44] or antibody versus placebo [45].

EoE diagnosis depends on the correlation of clinical signs and symptoms with esophageal biopsy pathology in the proper clinical setting, e.g. lack of clinical and histopathologic response to PPI therapy. After therapy targeted to treat EoE, both biopsy and clinical symptoms may improve $[44,45]$. However, a strong placebo effect may
Table 1. Dysregulated genes and pathologic features of EoE

\begin{tabular}{lll}
\hline Dysregulated gene & Pathologic feature & Reference \\
\hline Eotaxin-3 & inflammation & 14,16 \\
Carboxypeptidase A3, tryptase & inflammation & 15,16 \\
TSLP & inflammation & 46,48 \\
Periostin & inflammation & 49 \\
Filaggrin & epithelium & 50 \\
microRNA: $\quad$ miR-221, miR-223, miR-375 & inflammation & 51,52 \\
\hline
\end{tabular}

obscure the significance of the clinical improvement [45]. In some studies, inflammation was significantly diminished following therapy, including reduction of eosinophil granule-associated proteins, but symptoms did not improve significantly [41]. One possible explanation is that topical therapy does not result in improvements in the esophageal wall that surrounds the epithelium.

\section{Genetics}

EoE is diagnosed using both clinical and pathologic criteria in combination - truly a clinicopathologic diagnosis. EoE is also a 'genopathologic' disease. A unique transcriptome is identified in esophageal biopsies from affected patients [14], and several of those dysregulated genes correlate with several features of EoE esophageal biopsies (table 1). Eotaxin-3 is the most upregulated gene and it strongly promotes eosinophil infiltration into tissue [14, 16]. Thymic stromal lymphopoietin is a cytokine involved in multiple allergic processes that also promotes tissue inflammation in EoE [46-48]. Periostin, an extracellular matrix protein, is overexpressed in EoE and facilitates eosinophil adhesion to fibronectin [49]. Filaggrin is a member of the epithelial differentiation complex of genes and filaggrin expression is decreased in EoE, consistent with expansion of the less differentiated basal cell layer and reduction of the more differentiated suprabasal layers [50]. Several microRNAs are dysregulated in biopsies of active EoE and appear to contribute to Th2-polarized responses $[51,52]$. A recently developed test provides rapid evaluation of gene expression in esophageal tissue [53].

\section{Disclosure Statement}

The author declares that no financial or other conflict of interest exists in relation to the content of the article. 


\section{References}

-1 Furuta GT, Liacouras CA, Collins MH, Gupta SK, Justinich C, Putnam PE, Bonis P, Hassall E, Straumann A, Rothenberg ME, First International Gastrointestinal Eosinophil Research Symposium (FIGERS) Subcommittees: Eosinophilic esophagitis in children and adults: a systematic review and consensus recommendations for diagnosis and treatment. Gastroenterology 2007;133:1342-1363.

-2 Liacouras CA, Spergel JM, Ruchelli E, Verma R, Mascarenhas M, Semeao E, Flick J, Kelly J, Brown-Whitehorn T, Mamula P, Markowitz JE: Eosinophilic esophagitis: a 10-year experience in 381 children. Clin Gastroenterol Hepatol 2005;3:1198-1206.

-3 Assa'ad AH, Putnam PE, Collins MH, Akers RM, Jameson SC, Kirby CL, Buckmeier BK, Bullock JZ, Collier AR, Konikoff MR, Noel RJ, Guajardo JR, Rothenberg ME: Pediatric patients with eosinophilic esophagitis: an 8-year follow-up. J Allergy Clin Immunol 2007;119: 731-738.

-4 Liacouras CA, Furuta GT, Hirano I, Atkins D, Attwood SE, Bonis PA, Burks AW, Chehade M, Collins MH, Dellon ES, Dohil R, Falk GW, Gonsalves M, Gupta SK, Katzka DA, Lucendo AJ, Markowitz JE, Noel RJ, Odze RD, Putnam PI, Richter JE, Romero Y, Ruchelli E, Sampson HA, Schoepfer A, Shaheen NJ, Sicherer SH, Spechler S, Spergel JM, Straumann A, Weshil BK, Rothenberg ME, Aceves SS: Eosinophilic esophagitis: updated consensus recommendations for children and adults. J Allergy Clin Immunol 2011;128:3-20.

5 Dellon ES, Gonsalves N, Hirano I, Furuta GT, Liacouras CA, Katzka DA: ACG clinical guideline: evidenced based approach to the diagnosis and management of esophageal eosinophilia and eosinophilic esophagitis (EoE). Am J Gastroenterol 2013;108:679-692.

6 DeBrosse CW, Case JW, Putnam PE, Collins $\mathrm{MH}$, Rothenberg ME: Quantity and distribution of eosinophils in the gastrointestinal tract of children. Pediatr Dev Pathol 2006;9:210 218.

7 Walsh SV, Antonioli DA, Goldman H, Fox VL, Bousvaros A, Leichtner AM, Furuta GT: Allergic esophagitis in children. A clinicopathologic entity. Am J Surg Pathol 1999;23: 390-396.

8 Dellon ES, Fritchie KJ, Rubinas TC, Woosley JT, Shaheen NJ: Inter- and intraobserver reliability and validation of a new method for determination of eosinophil counts in patients with esophageal eosinophilia. Dig Dis Sci 2010;55:1940-1949.

-9 Gonsalves N, Policarpio-Nicolas M, Zhang Q, 2 Sambasiva Rao M, Hirano I: Histopathologic variability and endoscopic correlates in adults with eosinophilic esophagitis. Gastrointest Endosc 2006;64:313-319.

10 Molina-Infante J, Ferrando-Lamana L, Ripoll C, Hernandez-Alonso M, Mateos JM, Fernandez-Bermejo $M$, Dueñas $C$, FernandezGonzalez N, Quintana EM, Gonzalez-Nuñez
MA: Esophageal eosinophilic infiltration responds to proton pump inhibition in most adults. Clin Gastroenterol Hepatol 2011;9: 110-117.

-11 Hirano I, Moy N, Heckman MG, Thomas CS, Gonsalves N, Achem SR: Endoscopic assessment of the oesophageal features of eosinophilic oesophagitis: validation of a novel classification and grading system. Gut 2013;62: 489-495.

12 Lwin T, Melton SD, Genta RM: Eosinophilic gastritis: histopathological characterization and quantification of the normal gastric eosinophil count. Mod Pathol 2011;24:556-563.

13 Straumann A, Aceves SS, Blanchard C, Collins MH, Furuta GT, Hirano I, Schoepfer AM, Simon D, Simon H-U: Pediatric and adult eosinophilic esophagitis: similarities and differences. Allergy 2012;67:477-490.

14 Blanchard C, Wang N, Stringer KF, Mishra A, Fulkerson PC, Abonia JP, Jameson SC, Kirby C, Konikoff MR, Collins MH, Cohen MB, Akers R, Hogan SP, Assa'ad AH, Putnam PE, Aronow BJ, Rothenberg ME: Eotaxin-3 and a uniquely conserved gene-expression profile in eosinophilic esophagitis. J Clin Invest 2006; 116:536-547.

15 Abonia JP, Blanchard C, Buckmeier Butz B, Rainey HF, Collins MH, Stringer K, Putnam $\mathrm{PE}$, Rothenberg ME: Involvement of mast cells in eosinophilic esophagitis. J Allergy Clin Immunol 2010;126:140-149.

16 Blatman KS, Gonsalves N, Hirano I, Bryce PJ: Expression of mast-cell associated genes is upregulated in adult eosinophilic esophagitis and responds to steroid or dietary therapy. J Allergy Clin Immunol 2011;127:1307-1308.

17 Straumann A, Spichtin HP, Grize L, Bucher KA, Beglinger C, Simon HU: Natural history of primary eosinophilic esophagitis: a followup of 30 adult patients for up to 11.5 years. Gastroenterology 2003;125:1660-1669.

18 Aceves SS, Newbury RO, Dohil R, Bastian JF, Broide DH: Esophageal remodeling in pediatric eosinophilic esophagitis. J Allergy Clin Immunol 2007;119:206-212.

19 Chehade M, Sampson HA, Morotti RA, Magid MS: Esophageal subepithelial fibrosis in children with eosinophilic esophagitis. J Pediatr Gastro Nutr 2007:45:319-328.

20 Aceves SS, Newbury RO, Chen D, Mueller J, Dohil R, Hoffman H, Bastian JF, Broide DH: Resolution of remodeling in eosinophilic esophagitis correlates with epithelial response to topical corticosteroids. Allergy 2010;65: 109-116.

21 Lucendo AJ, Árias A, De Rezende LC, YagüeCompadre JL, Mota-Huertas T, GonzálezCastillo S, Cuesta RA, Tenias JM, Bellon T: Subepithelial collagen deposition, profibrogenic cytokine gene expression, and changes after prolonged fluticasone propionate treatment in adult eosinophilic esophagitis: a prospective study. J Allergy Clin Immunol 2011; 128:1037-1046.
22 Lieberman JA, Morotti RA, Konstantinou GN, Yershov O, Chehade M: Dietary therapy can reverse esophageal subepithelial fibrosis in patients with eosinophilic esophagitis: a historical cohort. Allergy 2012;67:1299-1307.

23 Vanderheyden AD, Petras RE, DeYoung BR, Mitros FA: Emerging eosinophilic (allergic) esophagitis: increased incidence or increased recognition? Arch Pathol Lab Med 2007;131: 777-779.

24 Whitney-Miller CL, Katzka D, Furth EE: Eosinophilic esophagitis: a retrospective review of esophageal biopsy specimens from 1992 to 2004 at an adult academic medical center. Am J Clin Pathol 2009;131:788-792.

25 Gill R, Durst P, Rewalt M, Elitsur Y: Eosinophilic esophagitis disease in children from West Virginia: a review of the last decade (1995-2004). Am J Gastroenterol 2007;102: 2281-2285.

26 Debrosse CW, Collins MH, Buckmeier Butz BK, Allen CL, King EC, Assa'ad AH, Abonia JP, Putnam PE, Rothenberg ME, Franciosi JP: Identification, epidemiology, and chronicity of pediatric esophageal eosinophilia, 19821999. J Allergy Clin Immunol 2010;126:112119

27 Debrosse CW, Franciosi JP, King EC, Buckmeier Butz BK, Greenberg AB, Collins $\mathrm{MH}$, Abonia JP, Assa'ad A, Putnam PE, Rothenberg ME: Long-term outcomes in pediatriconset esophageal eosinophilia. J Allergy Clin Immunol 2011;128:132-138.

28 Collins MH, Blanchard C, Abonia JP, Kirby C, Akers R, Wang N, Putnam PE, Jameson SA, Assa'ad AH, Konikoff MR, Stringer KF, Rothenberg ME: Clinical, pathologic and molecular characterization of familial eosinophilic esophagitis compared with sporadic cases. Clin Gastroenterol Hepatol 2008;6: 621-629.

29 Abonia JP, Wen T, Stucke EM, Grotjan T, Griffith MS, Kemme KA, Collins MH, Putnam PE, Franciosi JP, von Tiehl KF, Tinkle BT, Marsolo KA, Martin LJ, Ware SM, Rothenberg ME: High prevalence of eosinophilic esophagitis in patients with inherited connective tissue disorders. J Allergy Clin Immunol 2013;132:378-386.

30 Ngo P, Furuta GT, Antonioli DA, Fox VL: Eosinophils in the esophagus - peptic or allergic eosinophilic esophagitis? Case series of three patients with esophageal eosinophilia. Am J Gastroenterol 2006;101:1666-1670.

- 31 Rodrigo S, Abboud G, Oh D, DeMeester SR, Hagen J, Lipham J, DeMeester TR, Chandrasoma P: High intraepithelial eosinophil counts in esophageal squamous epithelium are not specific for eosinophilic esophagitis in adults. Am J Gastroenterol 2008;103:435-442.

32 Dranove JE, Horn DS, Davis MA, Kernek KM, Gupta SK: Predictors of response to proton pump inhibitor therapy among children with significant esophageal eosinophilia. J Pediatr 2009;154:96-100. 
33 Dohil R, Newbury RO, Aceves S: Transient PPI responsive esophageal eosinophilia may be a clinical sub-phenotype of pediatric eosinophilic esophagitis. Dig Dis Sci 2012;57: 1413-1419.

-34 Moawad FJ, Veerappan GR, Dias JA, Baker TP, Maydonovitch CL, Wong RK: Randomized controlled trial comparing aerosolized swallowed fluticasone to esomeprazole for esophageal eosinophilia. Am J Gastroenterol 2013;108:366-372.

- 35 Schroeder S, Capocelli KE, Masterson JC, Harris R, Protheroe C, Lee JJ, Furuta GT: Effect of proton pump inhibitor on esophageal eosinophilia. J Pediatr Gastroenterol Nutr 2013;56:166-172

36 Hirano I: Editorial: should patients with suspected eosinophilic esophagitis undergo a therapeutic trial of proton pump inhibition? Am J Gastroenterol 2013;108:373-375.

-37 Kirsch R, Bokhary R, Marcon MA, Cutz E: Activated mucosal mast cells differentiate eosinophilic (allergic) esophagitis from gastroesophageal reflux disease. J Pediatr Gastroenterol Nutr 2007;44:20-26.

-38 Dellon ES, Chen X, Miller CR, Fritchie KJ, Rubinas TC, Woosley JT, Shaheen NJ: Tryptase staining of mast cells may differentiate eosinophilic esophagitis from gastroesophageal reflux disease. Am J Gastroenterol 2011;106: 264-271.

39 Sridhara S, Ravi K, Smyrk TC, Kita H, Kephart GM, Weiler CR, Katzka DA: Increased numbers of eosinophils, rather than only etiology, predict histologic changes in patients with esophageal eosinophilia. Clin Gastroenterol Hepatol 2012;10:735-741.

40 Konikoff MR, Noel RJ, Blanchard C, Kirby C, Jameson SC, Buckmeier BK, Akers R, Cohen $\mathrm{MB}$, Collins MH, Assa'ad AH, Aceves SS, Putnam PE, Rothenberg ME: A randomized, double-blind, placebo-controlled trial of fluticasone propionate for pediatric eosinophilic esophagitis. Gastroenterology 2006; 131:1381-1391.
41 Alexander JA, Jung KW, Arora AS, Enders F, Katzka DA, Kephardt GM, Kita H, Kryzer LA, Romero Y, Smyrk TAC, Talley NJ: Swallowed fluticasone improves histologic but not symptomatic response of adults with eosinophilic esophagitis. Clin Gastroenterol Hepatol 2012; 10:742-749.

42 Dohil R, Newbury R, Fox L, Bastian J, Aceves $\mathrm{S}$ : Oral viscous budesonide is effective in children with eosinophilic esophagitis in a randomized, placebo-controlled trial. Gastroenterology 2010;139:418-429.

43 Straumann A, Conus S, Degen L, Felder S, Kummer M, Engel H, Bussman C, Beglinger C, Schoepfer A, Simon HU: Budesonide is effective in adolescent and adult patients with active eosinophilic esophagitis. Gastroenterology 2010;139:1526-1537.

44 Assa'ad AH, Gupta SK, Collins MH, Thomson M, Heath AT, Smith DA, Perschy TL, Jurgensen $\mathrm{CH}$, Ortega HG, Aceves SS: An antibody against IL-5 reduces numbers of esophageal intraepithelial eosinophils in children with eosinophilic esophagitis. Gastroenterology 2011;141:1593-1604.

45 Spergel JM, Rothenberg ME, Collins MH, Furuta GT, Markowitz JE, Fuchs G, O’Gorman MA, Abonia JP, Young J, Henkel T, Wilkins HJ, Liacouras CA: Reslizumab in children and adolescents with eosinophilic esophagitis: results of a double-blind, randomized, placebocontrolled trial. J Allergy Clin Immunol 2012; 129:456-463.

46 Rothenberg ME, Spergel JM, Sherrill JD, Annaiah K, Martin LJ, Cianferoni A, Gober L, Kim C, Glessner J, Frackelton E, Thomas K, Blanchard C, Liacouras C, Verma R, Aceves S, Collins MH, Brown-Whitehorn T, Putnam PE, Franciosi JP, Chiavacci RM, Grant SFA, Abonia JP, Sleiman PM, Hakonarson $\mathrm{H}$ : Common variants at $5 \mathrm{q} 22$ associate with pediatric eosinophilic esophagitis. Nat Genet 2010;42:289-291.

47 Sherrill JD, Gao PS, Stucke EM, Blanchard C, Collins MH, Putnam PE, Franciosi JP, Kushner JP, Abonia JP, Assa'ad AH, Kovacic MB, Myers JM, Bochner BS, He H, Hershey GK, Martin LJ, Rothenberg ME: Variants of thymic stromal lymphopoietin and its receptor associate with eosinophilic esophagitis. J Allergy Clin Immunol 2010;126:160-165.
8 Noti M, Wojno ED, Kim BS, Siracusa MC, Giacomin PR, Nair MG, Benitez AJ, Ruymann KR, Muir AB, Hill DA, Chikwava KR, Moghaddam AE, Sattentau QJ, Alex A, Zhou C, Yearley JH, Menard-Katcher P, Kubo M, Obata-Ninomiya K, Karasuyama H, Comeau MR, Brown-Whitehorn T, Malefyt RW, Sleiman PM, Hakonarson H, Cianferoni A, Falk GW, Wang M-L, Spergel JM, Artis D: Thymic stromal lymphopoietin-elicited basophil responses promote eosinophilic esophagitis. Nat Med 2013;19:1005-1013.

49 Blanchard C, Mingler MK, McBride M, Putnam PE, Collins $\mathrm{MH}$, Chang G, Stringer K, Abonia JP, Molkentin JD, Rothenberg ME: Periostin facilitates eosinophil tissue infiltration in allergic lung and esophageal responses. Mucosal Immunol 2008;1:289-296.

50 Blanchard C, Stucke EM, Burwinkel K, Caldwell JM, Collins MH, Ahrens A, Buckmeier BB, Jameson SC, Greenberg A, Kaul A, Franciosi JP, Kushner JP, Martin LJ, Putnam PE, Abonia JP, Wells SI, Rothenberg ME: Coordinate interaction between IL-13 and epithelial differentiation cluster genes in eosinophilic esophagitis. J Immunol 2010;184:40334041.

51 Lu TX, Sherrill JD, Wen T, Plassard AJ, Besse JA, Abonia JP, Franciosi JP, Putnam PE, Eby M, Martin LJ, Aronow BJ, Rothenberg ME: MicroRNA signature in patients with eosinophilic esophagitis, reversibility with glucocorticoids, and assessment as disease biomarkers. J Allergy Clin Immunol 2012;129:1064-1075.

52 Lu S, Mukkada VA, Mangray A, Cleveland K, Shillingford N, Schorl C, Brodsky AS, Resnick MB: MicroRNA profiling in mucosal biopsies of eosinophilic esophagitis patients pre and post treatment with steroids and relationship with mRNA targets. PLoS One 2012;7:e40676.

53 Wen T, Stucke E, Grotjan TG, Kemme K, Abonia JP, Putnam PE, Franciosi JP, Garza JM, Kaul A, King EC, Collins MH, Kushner JP, Rothenberg ME: Molecular diagnosis of eosinophilic esophagitis by gene expression profiling. Gastroenterology 2013, e-pub ahead of print. 